\title{
Practitioner Response to Rooney, Brown and Mesch Paper
}

\section{Cheryl L. Altinkemer}

is a Associate Vice President of Advancement at Purdue University. Purdue recently completed a $\$ 1.5$ bn dollar campaign, which raised over $\$ 1.7 \mathrm{bn}$. At Purdue since 1988, started her career as Development Director for the School of Consumer and Family Sciences. During a six-month sabbatical, Cheryl was fundraising consultant for Bosphorus University in Istanbul Turkey in 1994. Altinkemer has held leadership positions in, and is a member of the Association of Fundraising Professionals, the Council for Advancement and Support of Education, and the National Committee on Planned Giving. The Indiana Chapter of the Association of Fundraising Professionals recognized her as the 2002 Fundraising Executive of the Year. She is a founding board member and past chair of the national Women's Philanthropy Institute (WPI). Since WPI's merger with the IU Center on Philanthropy in 2004, she serves as an advisor and adjunct faculty member. The Women's Philanthropy Institute inspires, educates, and encourages women to effect change in the world through philanthropy.

International Journal of Educational Advancement (2007) 7, 243-248. doi:10.1057/palgrave.ijea.2150064

\section{Couples Giving-Strategies and Solutions}

Twenty years ago, as a new development director at a college of predominantly female alumni in a large land-grant research university, I found myself in a dilemma. The university had announced a campaign, but there was a perception that the college couldn't raise much money because so many of the graduates were women.

In a review of the household giving of our top alumnae, we found that giving was significant to the spouse's academic colleges or athletics, but very meager to the college once known as Home Economics.

The college had recently changed its name to Consumer and Family Sciences and the research performed was of interest to any person-male or female. Among the topics researched were healthy nutrition, child development, issues of gerontology, family finance, consumer issues, and even the hospitality industry. We knew the college had a great mission-but how to get alumnae households to begin at least giving equally within the university?

The dean at the time was wise and humorous. The college had the number one-ranked marriage and family therapy program as well as the number one hospitality program in the nation. During a weekend of activities for the highly regarded President's Council giving club (\$1,000 or more annually), we offered a "free lunch" performed by our hospitality students, along with a program outlining the stellar faculty research on consumers and families.

At the end of the program, the dean explained the importance of supporting this fine research and shared a bit about the marriage and family therapy program. 
He then offered a free year of therapy if the couples would begin to equalize their giving in the President's Council! He got a great chuckle, but I believe it was the first time on campus that anyone had even considered the thought!

After years of development work by wonderful donors, faculty, and staff, the college went from raising $\$ 250,000$ annually to over $\$ 2$ million annually. At the end of the most recent $\$ 1.5$ billion university campaign, the college raised over $\$ 20$ million over seven years! Quite a step from that meager beginning by paying attention to women and couples.

In those 20 years, I've studied all types of motivations to give by couples, and by women especially. I'm gratified to learn from the research performed by Rooney, Brown, and Mesch that this attention has not been for naught-that married women in couples are increasingly influencing household giving toward education. I try to keep up with the latest research, and yet a few items culled from past research have also helped me prepare strategies for major gifts. I've found that although each person and each couple are unique, there are some generalities that can help any fundraiser get started. A focus on gender differences, generational motivation, and philanthropic and giving styles are key factors to consider.

\section{Couples and Gender}

As Rooney, Brown, and Mesch report, as women become more affluent and generate wealth on their own, they influence the household to give toward education. As development professionals, it is helpful to know specifically how women are generating wealth. According to the most recent statistics reported by the US Internal Revenue Service (IRS) in 2005, 3.4 million, or 46.3 percent of the national's top wealth holders were women in 2001. This represents a 36 percent increase from the prior reporting in 1998. The IRS defines top wealth holders as individuals with gross assets in excess of $\$ 675,000$. These women had a combined net worth of US $\$ 6,291$ trillion, an increase of nearly 50 percent from that reported in 1998.

In the book, "The Millionaire Woman Next Door," by Dr. Thomas Stanley, it was stated that one in ten businesses with annual revenues of $\$ 1$ million or more is owned by women (excluding businesses inherited by women). This group of women donated on average 7 percent of their annual income compared to the 2 percent national average.

This group also allocated 4.7 percent of the household's annual realized income to adult children, grandchildren, nieces and nephews, brothers and sisters, and the like, while men allocated 1.5 percent. Only one in 20 of the women have never married.

Despite these financial gains, in a 2004 study by Prudential Financial, women say they lack financial knowledge and confidence to achieve goals. They respond to educational programs and need experience to feel confidence.

Since women tend to outlive their husbands by seven years and inherit the household wealth (in addition to parent's or other relative's inheritance), women 
are expected to hold much of the US \$41 trillion (Havens and Schervish, 1999) expected to pass from generation to generation over the next 50 years. With this knowledge in hand, it is important to understand how women and men may give differently.

In their book about women's giving, "Reinventing Fundraising," Martha Taylor and Sondra Shaw Hardy found that women are motivated to give by what they term the "Six C's": to create, be connected, to collaborate, make change, be committed, and to celebrate. They also discovered that women require a great deal of accountability and will be deliberate, and thus may take more time to make a decision and require a great deal of stewardship following the gift. And finally, they found women are more likely to be anonymous, and tend not to give to capital projects-which may reflect their lack of visibility within a capital campaign.

Scholar and author Deborah Tannen addressed communication differences between genders in her book "You Just Don't Understand." In fundraising, however, I find two aspects to be useful when having fundraising conversations. Tannen found men respond to "report" language while women respond to "rapport" language. A planned giving officer I worked with said when he visited men, he would first bring up the endowment rate of return and technical information, and then bring up what the gift impact. With women he would begin with the impact of the gift on students or faculty, and then discuss technical details.

The other Tannen difference I found to be helpful was her distinction between "competition" versus "collaboration." As mentioned previously, women are motivated by groups of women working together (collaborating) for a common cause. The enormous success of giving circles shows that women also like to give on an equal basis. I have found that men tend to respond when hearing their peers have given a particular sum-the competition to meet or beat that amount is motivating. While women may give the same amount of money, they want to know they're doing it together-thus collaborating.

\section{Generational Motivation}

Much has been written about the Greatest Generation or Traditionals; Builders or Primetime; The Boomers or 50 Plus or Generation Jones; Generation X, Y, and more. Reading generational marketing and demographic material is always helpful when determining a household strategy-especially when a couple may fall into different generation groups.

The Traditional age group tends to be loyal and are savers. They may be most comfortable with deferred giving as they are not comfortable with giving assets away they might need. These primetime women were often the first in their family to get an education and enthusiastically support it. Depending on how women acquired wealth, the Boomers may behave differently, but generally, Boomers don't believe in the status quo, are more grass roots oriented, and want to participate in their giving - they don't sit on the sidelines. Generation $\mathrm{X}$ and $\mathrm{Y}$ are just coming into their own for major gifts and so it will be 
interesting to see whether they follow their own path or those of their parents and grandparents.

In the Rooney, Brown, and Mesch report, when women become more affluent and move into the ranks of middle and upper classes, their bargaining power and decision-making ability within the household increases.

\section{Philanthropic Styles}

When fundraisers understand what motivates donors, they are more likely to develop trusting relationships and significant gifts. Prince and File studied 218 individuals in their book, The Seven Faces of Philanthropy: A New Approach to Cultivating Major Donors, 2001, who maintained \$1 million or more in a discretionary investment advisory account and contributed $\$ 50,000$ or more to a single nonprofit within two years. They found that philanthropists were motivated by the following areas: The Communitarian gave to help their communities prosper; The Devout were motivated by religious concerns; The Investor gives with one eye on the nonprofit cause, the other on personal or estate tax issues; the Socialite wants to make the world a better place and have a good time doing it; the Repayer personally benefited from the organization; the Altruist has a moral imperative to give; and the Dynast is motivated by family tradition, although younger dynasts seek out new causes.

These styles are often referred to as the "Seven Faces of Philanthropy." Often, a couple may fit different philanthropic styles and as you learn more about their individual styles, you may need to blend them for a household appeal.

\section{Gender Giving Styles}

Women tend to be checkbook givers and give small amounts to many causes. Men tend to focus their larger gifts on fewer institutions to have greater impact-which was also confirmed in the research by Rooney, Brown, and Mesch. When working with women, it has been helpful for me to have them write out the amount of money they give within a year, and then multiply it by their remaining life expectancy. If they understand how much they will give away in their lifetime and the impact focused giving can have, it may be easier for them give to their passion as opposed to giving just because an organization needs funds. By discovering their passion and developing a giving plan, they also have the power to say no to causes for which they have less interest.

Cindy Sterling, a development consultant in New York, compared alumnae of women's colleges with alumni of co-ed colleges that formerly had been male to see if their planned giving approached would be different. In her Planned Giving Today, December 2000 article, she shared research focused on small liberal arts colleges in the Northeast that had just completed capital campaigns. She found women gave, on average, 32 per cent of their total gifts through planned giving (life income gifts + matured bequests). Men gave 24 per cent of their campaign total through planned giving. Of those planned gifts, 10.4 per cent of the women contributed with a life income gifts, and 21.8 per cent gave through a matured 
bequest. Men contributed 17 per cent to life income gifts, while giving only seven per cent through a matured bequest.

The implication for the planned giving field is tremendous. The National Council on Planned Giving's report, Planned Giving in the United States 2000: A Survey of Donors, found that 53 percent of charitable bequest donors are women, while only 44 percent of women use charitable remainder trusts as a vehicle for their gifts. Although women are not less knowledgeable, they lack experience and confidence. Women are intimidated by complex financial decisionmaking. Women also fear outliving their assets and do not want to be a burden to their family, and so are less likely to give major gifts in their lifetime. With women living longer than men, and holding the some $\$ 41$ trillion to be inherited over the next 50 years, the opportunity for planned giving using deferred assetsespecially will bequests-is impressive. Although educational institutions may prefer nonrevocable gifts, the long-term impact of bequests can transform a university with sizeable gifts.

\section{Conclusion}

The paper by Rooney, Brown, and Mesch reinforces what I've come to understand anecdotally over the past 20 years in my work at Purdue University, but also with the Women's Philanthropy Institute at the Indiana University Center on Philanthropy. Women are increasingly influencing the decision to give to education, as well as the amount to be given. The more we learn about women's motivations and provide philanthropic and financial programs to increase their confidence, the more educational institutions will benefit.

Although the paper found that women have a greater influence on the decision to give to education, other research found that households in which the male partner decides on the charitable gifts are the larger donors. Educational institutions must provide educational programming for women and training for their fundraising staff to reap the benefits of larger gifts from the women in the household.

Understanding gender differences, generational motivations, and philanthropic styles can help development professionals better prepare household strategies. Through screening services and our research departments, we often understand the capacity to give, connections, and linkages to our organizations. Understanding the culture our donors experience is also important to obtaining effective gifts that will have a great impact on our society.

\section{References}

Havens, J.J. and Schervish, P.C. (1999), "Millionaires and the Millennium: New Estimates of the Forthcoming Wealth Transfer and the Prospects for a Golden Age of Philanthropy," Social Welfare Institute, Boston, October 19, 1999.

Prince, R., File, K. (1993), "The Seven Faces of Philanthropy: A New Approach to Cultivating Major Donors," Josey-Bass, 2001. 
Prudential Financial Inc. (2004), "Study of 1,134 women," Wall Street Journal, 6/1/2004.

Shaw, S. and Taylor, M. (1995), Reinventing Fundraising, Jossey-Bass Publishers, San Francisco.

Sterling, C. (2000), Gender Difference in Planned Giving: The Way Women Give; Planned Giving Today, December 2000

Tannen, D. (1990), You Just Don't Understand, William and Morrow and Co., New York.

Taylor, M. and Shaw-Hardy, S. (2006), The Transformative Power of Women's Philanthropy, Jossey-Bass Publishers, San Francisco.

The National Council on Planned Giving's report, Planned Giving in the United States 2000: A Survey of Donors.

Thomas, S.J. (2004), Millionaire Women Next Door, Andrews McMeel Publishing, Kansas City, MO. 